\title{
An unnecessary hindrance? A critical examination of the appropriateness of statutory limitation periods in Stolen Generations compensation claims
}

\author{
AMELIA E. NOBLE
}

\section{Abstract}

This article examines the appropriateness of statutory limitation periods in litigation by Stolen Generations. Stolen Generations are those Aboriginal and Torres Strait Islander children who were forcibly removed from their families by successive Australian governments throughout the twentieth century. This article argues that limitation periods should be removed for three main reasons. First, Stolen Generations often did not have the opportunity to bring actions for compensation against the government due to the nature of the harm suffered. Second, limitation periods simply delay proceedings unnecessarily, because judges will hear these cases 'on their merits' before deciding if a claim is statute-barred. Third, failing to remove limitation periods for Stolen Generations litigants presents a double standard when considering they have been waived for other litigants, such as British child migrants.

\section{Introduction}

Between the late 1800 s and 1970 s, a series of state-sanctioned policies promoted and facilitated the forced removal of Aboriginal and Torres Strait Islander children from their families and communities. ${ }^{1}$ These children were made to live in 'institutions that

1 It should be noted that while removal of Indigenous children was only official policy between 1905 and 1969, removals took place outside this period. There is evidence to suggest removals continued into the 1980s: Randall Kune, 'The Stolen Generations in Court: Explaining the Lack of Widespread Litigation by Members of the Stolen Generations' (2011) 30(1) University of Tasmania Law Review 32; Australian Human Rights and Equal Opportunity Commission, National Inquiry into the Separation of Aboriginal and Torres Strait Islander Children from Their Families, Bringing Them Home (1997) 217. 
bore no resemblance to home', ${ }^{2}$ often never seeing their families again. ${ }^{3}$ For many, this treatment resulted in lasting psychiatric injury, ${ }^{4}$ a loss of culture and identity (due to denied contact with their Aboriginality), ${ }^{5}$ and cross-generational social and economic difficulties that are still playing out. ${ }^{6}$ In 1997, the National Inquiry into the Separation of Aboriginals and Torres Strait Islanders from their Families and Culture $^{7}$ delivered the Bringing Them Home Report (the BTHR). The BTHR found that the removal of Aboriginal children from $1951^{8}$ constituted genocide under the 1948 Convention. ${ }^{9}$ It also confirmed that sexual abuse of Aboriginal and Torres Strait Islander children was widespread and institutionalised. ${ }^{10}$ Those affected by these long-term human rights violations have become known as the Stolen Generations. ${ }^{11}$

Claims for compensation by Stolen Generations have been 'demonstrably unsuccessful'. ${ }^{12}$ While the recent decision in Trevorrow v. South Australia ${ }^{13}$ has 'shone light into a previously dark litigation tunnel', ${ }^{14}$ the litigation path for Stolen Generations seeking compensation remains riddled with barriers. ${ }^{15}$ One such barrier is the application of statutory limitation periods (SLPs), which limit the time period within which a person can bring an action in court. The nature of the harm suffered by many members of the Stolen Generations means that despite often being aware of abuses from an early age, victims don't have the 'psychological fortitude' to address their trauma until later in life. ${ }^{16}$ In Stolen Generations litigation, governments continue to actively pursue SLPs as a defence, ${ }^{17}$ creating a conundrum for litigants because they must prove that the judicial discretion to extend the SLP should be exercised.

2 Cubillo v. Commonwealth of Australia [1999] FCA 518, [2].

3 Australian Human Rights and Equal Opportunity Commission, National Inquiry into the Separation of Aboriginal and Torres Strait Islander Children from Their Families, Bringing Them Home (1997).

4 Ibid., 77, 158, 336.

5 Chris Cuneen and Julia Grix, 'The Limitations of Litigation in Stolen Generations Cases', (Research Discussion Paper No. 15, Australian Institute of Aboriginal and Torres Strait Islander Studies, 2004) 10.

6 Australian Human Rights and Equal Opportunity Commission, above in n 3, 154.

7 Ibid.

8 The 'official policy of Assimilation' was introduced in 1951: Roslyn Atkinson, 'Denial and Loss: Obstacles to Litigation in Stolen Generation Cases' (2006) 12(1-2) Hungarian Journal of English and American Studies, 49.

9 Convention on the Prevention and Punishment of the Crime of Genocide, opened for signature 9 December 1948, 78 UNTS 277 (entered into force 12 January 1951) art. 2(e).

10 Australian Human Rights and Equal Opportunity Commission, above in n 3, 167, 263 (Recommendation 14).

11 The term 'Stolen Generations' was coined by historian Peter Read, and in 2001 was included in the Australian Oxford Dictionary. See: Peter Read, Aboriginal Children's Research Project, New South Wales Government, The Stolen Generations: The Removal of Aboriginal Children in New South Wales 1883 to 1969 (1982); B Moore (ed.), The Australian Oxford Dictionary, (5th ed., 2001) 1087-8.

12 Antonio Buti, 'The Stolen Generations and Litigation Revisited' (2008) 32 Melbourne University Law Review 382.

13 Trevorrow v. South Australia (2007) 98 SALR 136.

14 Ibid., 383.

15 Roslyn Atkinson, 'Denial and Loss: Obstacles to Litigation in Stolen Generation Cases' (2006) 12(1)

Hungarian Journal of English and American Studies 47, 48.

16 Ibid.

17 Williams v. The Minister, Aboriginal Land Rights Act 1983 [1990] NSWSC 843; Trevorrow (2007) 98 SALR 136; Cubillo [1999] FCA 518. 
The difficulties that Aboriginal and Torres Strait Islander peoples face in accessing compensation represent a failure of the 'beneficiaries of colonialism to take responsibility for historical injustice. ${ }^{18}$ This article will argue that remedying this failure necessarily requires that governments waive SLPs in Stolen Generations cases. Alternatively, judges should uniformly apply their discretionary power to extend SLPs so Stolen Generations claims can be heard. There are three key reasons behind this. First, the failure to bring actions within a limitation period is most often due to government control over Stolen Generations and the nature of the harm inflicted upon them. ${ }^{19}$ Second, SLPs delay proceedings, make litigation more costly and deter potential claimants, counteracting the recommendations of the BTHR that the path to compensation for Stolen Generations be efficient and not waylaid by technicalities. ${ }^{20}$ Third, when comparing Stolen Generations compensation claims with other compensation claims for state-sanctioned injustices, such as the 'child migrant' cases, there is a visible double standard. This double standard is also visible in state legislative provisions, casting doubt on the degree to which removal of SLPs will unfairly prejudice defendants.

\section{Background to SLPS}

Every jurisdiction in Australia contains a statute of limitations ${ }^{21}$ restricting the period of time in which a person can bring a civil claim to the court. This time period is usually between three ${ }^{22}$ and six years. ${ }^{23}$ Statutes of limitations generally provide judges the discretion to extend SLPs if 'special circumstances' 24 exist and the defendant is not likely to suffer significant disadvantage or unfair prejudice. ${ }^{25}$ The onus is on the plaintiff to rebut the presumption that the defendant's ability to defend has been affected due to the delay in proceedings. ${ }^{26}$ Limitation periods generally do not apply in criminal claims, ${ }^{27}$ but apply to civil claims for damages, in the areas of personal injury, negligence, wrongful imprisonment and breaches of

18 Rosanne Kennedy, 'Australian Trials of Trauma: The Stolen Generations in Human Rights, Law and Literature' (2011) Comparative Literature Studies 48 (3), 334.

19 Williams [1990] NSWSC 843; Trevorrow (2007) 98 SALR 136. Cubillo [1999] FCA 518 is the exception.

20 Buti, above in $\mathrm{n} 12,417$.

21 Limitation Act 1969 (NSW); Limitation of Actions Act 1958 (VIC); Limitations of Actions Act 1936 (SA); Limitation Act 2005 (WA); Limitation of Actions Act 1974 (QLD); Limitation Act 1974 (TAS); Limitation Act 1985 (ACT); Limitation Act 1981 (NT).

22 See e.g. Limitation Act (NT) ss 12(1)(b), 12(2)(a), 36, 4(1); Limitation Act 2005 (WA) s. 14.

23 See e.g. Limitation Act 1969 (NSW) s. 14(1).

24 Cuneen and Grix, above in n 5, 32.

25 Ibid.

26 Ibid.

27 New South Wales Department of Justice, 'Limitation Periods in Civil Claims for Child Sexual Abuse' (Discussion Paper, 2015) 38; See also, Limitations of Actions Act 1958 (Vic) s. 27P. 
statutory duty. ${ }^{28}$ They may also apply to equitable claims for breach of fiduciary duty 'by analogy'. ${ }^{29}$ The first litigated claim for compensation from Stolen Generations victims took place in $1997,{ }^{30}$ and, as a result, SLPs have always needed to be overcome by plaintiffs.

\section{Is application of SLPs appropriate?}

\section{A problem for Parliament?}

Some may argue that responsibility for making compensation more accessible for Stolen Generations does not rest with courts or defendants, and that it does not need to involve the removal of SLPs. Limitation periods are a longstanding fixture of Australian civil law designed to ensure fairness to the defendant, ${ }^{31}$ and arguably the need for compensation is not a good enough reason to justify their non-use in Stolen Generations cases. Instead, the responsibility for change lies with the federal government to develop a national compensation scheme for Stolen Generations victims. ${ }^{32}$

While the need for such a scheme is uncontroversial, ${ }^{33}$ this argument does not address the reality that the federal government has been reluctant to establish an Administrative Compensation Board. ${ }^{34}$ There has similarly been reluctance to introduce schemes at the state and territory level, with the exceptions of South Australia and Tasmania. ${ }^{35}$ Claims are likely to continue proceeding through the court system, ${ }^{36}$ and an influx should even be expected given the 'renewed optimism ${ }^{37}$ sparked by the success of Trevorrow. Canadian scholar Jennifer Llewellyn argues that Stolen Generations will still pursue litigation because it has the advantage of being able to develop precedent, ${ }^{38}$ ensuring that other victims will be treated similarly.

\footnotetext{
28 Ibid.

29 Williams [1990] NSWSC 843, [509] (Brennan CJ).

30 Kruger v. Commonwealth (1997) 190 CLR 1.

31 Brisbane South Regional Health Authority v. Taylor [1996] 186 CLR 541, 552 (McHugh J).

32 See e.g., David Hollinsworth, 'More Than Words Needed to Make Apology Count', The Sydney Morning Herald (Sydney), 14 February 2008, 17; Rhianna King, 'Compensation Demands Grow', The West Australian (Perth), 14 February 2008, 7.

33 Australian Human Rights and Equal Opportunity Commission, above in n 3, 247, 271.

34 Marcelle Burns, 'The Unfinished Business of the Apology: Senate Rejects Stolen Generation Compensation Bill 2008' (2008) 7(8) Indigenous Law Bulletin, 10.

35 Stolen Generations of Aboriginal Children Act 2006 (Tas), ss 4, 5. Ex gratia payments of up to $\$ 5,000$ per individual and \$20,000 per family have been made available to Stolen Generations members.

36 Simon Young, 'The Long Way Home: Reparation for the Removal of Aboriginal Children' (1998) 20(1)

University of Queensland Law Journal 71, 79.

37 Buti, above in $\mathrm{n} 12,384$.

38 Llewellyn, Jennifer, 'Dealing with the Legacy of Native Residential School Abuse in Canada: Litigation, ADR and Restorative Justice (2002) 52(3) The University of Toronto Law Journal 253, 266.
} 
Consequently, the question of the appropriateness of SLPs becomes significant. Young suggests the hundreds ${ }^{39}$ of legal challenges lodged since 1996 highlight the need for the Australian judiciary to develop the law of tort and equity to take into account 'specific harms resulting from Australia's assimilationist history' ${ }^{40}$ Antonio Buti supports this idea, arguing the judiciary needs to 'reassess its timidity'. ${ }^{41}$ Judges have discretion to extend SLPs in special circumstances, ${ }^{42}$ and thus the argument that this discretion should be universally applied in Stolen Generations claims is a strong one.

The responsibility does not lie solely with the judiciary in litigated compensation claims. Buti stresses that limitation periods need not be an inevitable hurdle to Stolen Generations litigation. ${ }^{43}$ This is because SLPs are only enacted if pleaded by defendants ${ }^{44}$ (in the context of Stolen Generations litigation, defendants are governments or government bodies). ${ }^{45}$ Cuneen and Grix argue that we should look to the Canadian approach to compensation, which has developed in such a way that it accommodates the historical treatment of Indigenous peoples. ${ }^{46}$ In Canada, the government has waived all limitations in litigation over the Aboriginal residential school experience. ${ }^{47}$ This can be contrasted with the Australian approach, where the defence has sadly been pursued 'with great vigor'. ${ }^{48}$

Ideally, legislative changes should be made to state statutes of limitations exempting Stolen Generations claimants from the application of the SLP. Until this happens (or a national compensation scheme is developed), the inappropriateness of SLPs in Stolen Generations claims remains an issue for the courts. Judges should follow the lead of Gray J in Trevorrow and uniformly extend SLPs for Stolen Generations. In the alternative, government defendants should not pursue SLPs as a defence.

\section{The nature of the harm}

The first reason why SLPs are inappropriate relates to the nature of the harm suffered by Stolen Generations claimants. In Trevorrow v. South Australia, ${ }^{49}$ Gray $\mathrm{J}$ found in favour of the plaintiff on the issue of an extension of time under

\footnotetext{
39 Young, above in n 36, 79.

40 Ibid., 85.

41 Buti, above in $\mathrm{n} 12,383$.

42 Cuneen and Grix, above in n 5, 32.

43 Buti, above in $\mathrm{n} 12,417$.

44 Ibid.

45 For an example of a government body defendant see Johnson v Department of Community Services (2000) 5(4)

AILR 49.

46 Cuneen and Grix, above in n 5, 5.

47 Julie Cassidy, 'The Stolen Generations - Canada and Australia: The Legacy of Assimilation' (2004) 11 Deakin

Law Review 131, 176.

48 Buti, above in n 12, 417. See also, Cubillo (trial) (2000) 103 FCR, 445 (O’Loughlin J); Williams (trial) (1999)

25 Fam LR 86, 90, 243 (Abadee J); Trevorrow (2007) 98 SALR 136, 332 (Gray J).

49 Trevorrow (2007) 98 SASR 136.
} 
s. 48(3)(b)(i) (new material fact relevant to the proceedings) and s. 48(3)(b)(ii) (defendant's conduct causes plaintiff's failure to commence proceedings in time).$^{50}$ Not every Stolen Generations case is likely to involve finding of new material facts. However, the same cannot be said for the role of State conduct in contributing to a failure to commence proceedings. ${ }^{51}$ Stolen Generations cases, by nature, involve State control contributing to lack of action on the part of the plaintiff. This is consistent with Deane J's definition in Hawkins v. Clayton: ${ }^{52}$

If a wrongful action or breach of duty by one person not only causes unlawful injury to another but, while its effect remains, effectively precludes that other from bringing proceedings to recover the damage to which he is entitled, that other person is doubly injured. ${ }^{33}$

The BTHR identified that psychological harm, physical harm, and financial and educational disadvantage resulting from their removal from family and placement in State care prevents Stolen Generations victims from seeking compensation until later in life. ${ }^{54}$ The cases of Trevorrow, Williams and Johnson all demonstrate that Stolen Generations were, by nature, 'doubly injured'. ${ }^{55}$ The necessity for SLPs in Stolen Generations actions for compensation is thus questionable.

\section{A waste of time and resources}

The drive by governments to dismiss actions based on SLPs reveals a stark insensitivity to 'the importance of the case being seen to have its day in court ${ }^{\text {' }}{ }^{6}$ and more often than not ${ }^{57}$ results in a waste of time and resources.

One of the key recommendations in the BTHR was that reparations should not be hindered by 'legal technicalities'. ${ }^{58}$ The van Boven Principles imply that the mechanism for establishing compensation should be 'expeditious' as well as culturally appropriate. ${ }^{59}$ Despite this, the body of case law relating to Stolen Generations compensation claims is itself evidence that SLPs most often result in prolonged proceedings, with no overall benefit to plaintiff or defendant.

50 Limitation of Actions Act 1936 (SA).

51 Williams (trial) (1999) 25 Fam LR 86, 90, 243 (Abadee J); Trevorrow (2007) 98 SALR 136, 332 (Gray J); Johnson (2000) 5(4) AILR 49.

52 (1988) 164 CLR 539.

53 Hawkins v. Clayton (1988) 164 CLR 539, 590, cited in Trevorrow (2007) 98 SASR 136, 330 (Gray J).

54 Australian Human Rights and Equal Opportunity Commission, above in n 3, 287, 398, 451.

55 Hawkins v. Clayton (1988) 164 CLR 539, 590, cited in Trevorrow (2007) 98 SASR 136, 330 (Gray J).

56 M. Flynn and S. Stanton, 'Trial by Ordeal: The Stolen Generation in Court' (2000) 25(2) Alternative Law Journal, 75-76.

57 Cubillo [1999] FCA 518 being the only exception.

58 Ibid.

59 Australian Human Rights and Equal Opportunity Commission, above in n 3, 88. 
In Williams, the plaintiff applied for an order extending the time within which proceedings could be considered under the Limitation Act 1969 (NSW). At trial, Studdert J declined to extend the limitation period because it was 'neither just nor reasonable to do so'. ${ }^{60}$ This decision was reversed in the NSW Court of Appeal in 1994. ${ }^{61}$ Similarly, in Johnson v. Department of Community Services, ${ }^{62}$ the trial judge declined to extend the limitation period for reasons of unfair prejudice, but this too was overturned on appeal. ${ }^{63}$ Even in Cubillo, ${ }^{64}$ a rare case where the Commonwealth succeeded in dismissing of the plaintiff's action on the basis of an SLP, O'Loughlin $\mathrm{J}$ still insisted that the merits of the case be heard:

[T]hese cases are of such importance- not only to the individual applicants and to the larger Aboriginal community, but also to the nation as a whole-that nothing short of a determination on the merits ... is warranted. ${ }^{65}$

Thus, whether or not a judge decides to extend the SLP, the merits of these cases will inevitably be heard. Given the appeal decisions in Williams and Johnson, and the decision in Trevorrow, it is increasingly clear that SLPs are becoming redundant and only serve to unnecessarily delay proceedings and deter potential Stolen Generations litigants.

\section{A double standard}

Provisions in various limitation statutes and the judicial treatment of British 'child migrant' cases cast doubt on the degree of 'unfair prejudice' conferred upon defendants because of an extension of time, and further highlight why SLPs are inappropriate in Stolen Generations litigation. ${ }^{66}$ Section 50E of the Limitation Act 1969 (NSW) extends the personal injury SLP for children harmed by their parents, guardians or 'close associates' to a period of 12 years after the plaintiff turns $25 .{ }^{67}$ When such provisions are in place, it is difficult to understand why legislation should not similarly adapt to accommodate for Stolen Generations children who suffered in State care. This double standard is also evident in litigation by British 'child migrants' and 'forgotten children'. In these instances, Australian courts have demonstrated a willingness to extend SLPs, and, importantly, defendants have waived SLPs more frequently than they have in litigation from Stolen Generations. ${ }^{68}$

60 Williams (Unreported, Supreme Court of NSW), 25 August 1993, 36.

61 Williams [No 1] (1994) 35 NSWLR 497.

62 (2000) 5(4) AILR 49.

63 Cuneen and Grix, above in n. 7, 10.

64 [1999] FCA 518.

65 Cubillo [1999] FCA 518, 203.

66 See, for example, Limitations Act 1969 (NSW) s. 50E.

67 Limitation Act 1969 (NSW) s. 50E.

68 Rundle v. the Salvation Army (South Australian Property Trust) and Anor [2007] NSWSC 443; Giles \& Anor v. Commonwealth of Australia \& Ors [2011] NSWSC 582; Kathleen Daly, 'Conceptualising Responses to Institutional Abuse of Children (2014) 26(1) Current Issues In Criminal Justice 5, 11. 
SLPs are a 'defence based on avoidance' serving to 'perpetuate the damage caused by the policies in issue'. ${ }^{69}$ Our laws acknowledge that provisions like section $50 \mathrm{E}$ are not unduly 'oppressive' or 'cruel'70 to defendants, and it should be acknowledged that the act of waiving SLPs in Stolen Generations claims is not either.

\section{Conclusion}

SLPs are not appropriate in Stolen Generations claims. The nature of the harm suffered by Stolen Generations is likely to always fulfil criteria necessary to engage the judicial discretion to extend the SLP. The use of SLPs as a defence merely results in wasted time and resources, and added costs for already under-resourced plaintiffs. Lastly, there is undeniably a double standard with the judicial treatment of compensation claims in Stolen Generations cases when compared to cases involving non-Indigenous children.

To accommodate for this, both government and judiciary must adapt. The Australian Government should agree to waive SLPs for Stolen Generations litigants, following Canada's lead. Until this happens, the courts have a responsibility to uniformly extend SLPs to Stolen Generations so their claims can be heard 'on their merits'. ${ }^{71}$

\section{Bibliography}

\section{Journal articles/books/working papers}

Atkinson, Roslyn, 'Denial and Loss: Obstacles to Litigation in Stolen Generation Cases' (2006) 12(1-2) Hungarian Journal of English and American Studies 47.

Australian Human Rights and Equal Opportunity Commission, National Inquiry into the Separation of Aboriginal and Torres Strait Islander Children from Their Families, Bringing Them Home (1997).

Burns, Marcelle, 'The Unfinished Business of the Apology: Senate Rejects Stolen Generation Compensation Bill 2008' (2008) 7(8) Indigenous Law Bulletin 10.

Buti, Antonio, 'Reparations, Justice Theories and Stolen Generations' (2008) 34 University of Western Australia Law Review 168.

Buti, Antonio, 'The Stolen Generations and Litigation Revisited' (2008) 32 Melbourne University Law Review 382.

69 M. Flynn and S. Stanton, 'Trial by Ordeal: The Stolen Generation in Court' (2000) 25(2) Alternative Law Journal 76.

70 Brisbane South Regional Health Authority v. Taylor [1996] 186 CLR 541, 552 (McHugh J).

71 Cubillo [1999] FCA 518, 203 (O’Loughlin J). 
Cassidy, Julie 'The Stolen Generations_Canada and Australia: The Legacy of Assimilation' (2004) 11 Deakin Law Review 131.

Clarke, Jennifer, 'Cubillo v Commonwealth Case Note' (2001) 25(1) Melbourne University Law Review 218.

Cuneen, Chris and Julia Grix, 'The Limitations of Litigation in Stolen Generations Cases', (Research Discussion Paper No 15, Australian Institute of Aboriginal and Torres Strait Islander Studies, 2004).

Daly, Kathleen, 'Conceptualising Responses to Institutional Abuse of Children' (2014) 26(1) Current Issues In Criminal Justice 5.

Flynn, M. and S. Stanton, 'Trial by Ordeal: The Stolen Generation in Court' (2000) 25(2) Alternative Law Journal 75.

Kennedy, Rosanne, 'Australian Trials of Trauma: The Stolen Generations in Human Rights, Law and Literature' (2011) 48(3) Comparative Literature Studies.

Kune, Randall, 'The Stolen Generations in Court: Explaining the Lack of Widespread Litigation by Members of the Stolen Generations' (2011) 30(1) University of Tasmania Law Review.

Llewellyn, Jennifer, 'Dealing with the Legacy of Native Residential School Abuse in Canada: Litigation, ADR and Restorative Justice' (2002) 52(3) The University of Toronto Law Journal 253.

Moore, B (ed.), The Australian Oxford Dictionary (5th ed., 2001).

New South Wales Department of Justice, 'Limitation Periods in Civil Claims for Child Sexual Abuse’ (Discussion Paper, 2015).

Read, Peter, Aboriginal Children's Research Project, New South Wales Government, The Stolen Generations: The Removal of Aboriginal Children in New South Wales 1883 to 1969 (1982).

Young, Simon, 'The Long Way Home: Reparation for the Removal of Aboriginal Children' (1998) 20(1) University of Queensland Law Journal 71.

\section{Cases}

Brisbane South Regional Health Authority v. Taylor [1996] 186 CLR 541

Cubillo v. Commonwealth of Australia [1999] FCA 518

Giles \& Anor v. Commonwealth of Australia \& Ors [2011] NSWSC 582

Hawkins v. Clayton (1988) 164 CLR 539 
Johnson v. Department of Community Services (2000) 5(4) AILR 49

Kruger v. Commonwealth (1997) 190 CLR 1

Rundle v. the Salvation Army (South Australian Property Trust) and Anor [2007] NSWSC 443

Trevorrow v. South Australia [No.5] (2007) 98 SASC 285

Williams v. Minister, Aboriginal Land Rights Act 1983 (Unreported, Supreme Court of NSW), 25 August 1993

Williams v. Minister, Aboriginal Land Rights Act 1983 [No 1] (1994) 35 NSWLR 497

Williams v. The Minister, Aboriginal Land Rights Act 1983 [No 2] (1999) NSWSC 843

\section{Legislation}

Aboriginals Ordinance 1918 (NT)

Limitation Act 1935 (WA)

Limitation Act 1969 (NSW)

Limitation Act 1974 (Tas)

Limitation Act 1981 (NT)

Limitation Act 1985 (ACT)

Limitation Act 2005 (WA)

Limitation of Actions Act 1958 (Vic)

Limitation of Actions Act 1974 (Qld)

Limitations of Actions Act 1936 (SA)

Stolen Generations of Aboriginal Children Act 2006 (Tas)

\section{Treaties}

Convention on the Prevention and Punishment of the Crime of Genocide, opened for signature 9 December 1948, 78 UNTS 277 (entered into force 12 January 1951). 


\section{Other}

Hollinsworth, David, 'More Than Words Needed to Make Apology Count', The Sydney Morning Herald (Sydney), 14 February 2008, 17.

King, Rhianna, 'Compensation Demands Grow', The West Australian (Perth), 1 February 2008, 7.

Pearson, Noel, 'Contradictions Cloud the Apology to the Stolen Generations', The Australian (online), 12 February 2008, www.theaustralian.com.au/news/ inquirer/when-words-arent-enough/story-e6frg6z6-1111115528371 
This text is taken from The ANU Undergraduate Research Journal, Volume Eight, 2016, edited by Daniel McKay, published 2017 by ANU eView, The Australian National University, Canberra, Australia.

dx.doi.org/10.22459/AURJ.08.2016.09 